ARTICLE

\title{
Lethal microbial blooms delayed freshwater ecosystem recovery following the end-Permian extinction
}

Chris Mays (1) ${ }^{1 凶}$, Stephen McLoughlin (10) ${ }^{1}$, Tracy D. Frank ${ }^{2}$, Christopher R. Fielding (1) ${ }^{2}$, Sam M. Slater ${ }^{1} \&$ Vivi Vajda (iD 1 约

Harmful algal and bacterial blooms linked to deforestation, soil loss and global warming are increasingly frequent in lakes and rivers. We demonstrate that climate changes and deforestation can drive recurrent microbial blooms, inhibiting the recovery of freshwater ecosystems for hundreds of millennia. From the stratigraphic successions of the Sydney Basin, Australia, our fossil, sedimentary and geochemical data reveal bloom events following forest ecosystem collapse during the most severe mass extinction in Earth's history, the endPermian event (EPE; c. 252.2 Ma). Microbial communities proliferated in lowland fresh and brackish waterbodies, with algal concentrations typical of modern blooms. These initiated before any trace of post-extinction recovery vegetation but recurred episodically for >100 kyrs. During the following 3 Myrs, algae and bacteria thrived within short-lived, poorly-oxygenated, and likely toxic lakes and rivers. Comparisons to global deep-time records indicate that microbial blooms are persistent freshwater ecological stressors during warmingdriven extinction events.

\footnotetext{
${ }^{1}$ Department of Palaeobiology, Swedish Museum of Natural History, Box 50007, SE-104 05 Stockholm, Sweden. ${ }^{2}$ Department of Earth \& Atmospheric

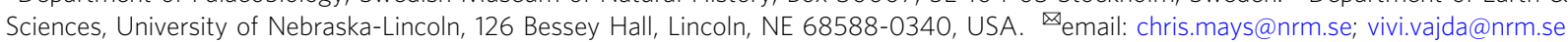


A lgae and photosynthetic bacteria form the foundations of aquatic food webs, but their unconstrained proliferation can be lethal to animals. High abundances promote poorly oxygenated waters upon their death and decomposition, deplete dissolved oxygen via respiration during dark intervals, and many have toxic metabolic by-products ${ }^{1,2}$. Bloom events of microscopic algae (microalgae) and bacteria are triggered by high temperatures $^{1-3}$ and nutrient influx (e.g., from soil erosion following deforestation $)^{1,3}$. Since they are exacerbated by increasing $\mathrm{CO}_{2}$ and temperature, harmful microbial blooms are projected to become increasingly common into the future ${ }^{2,4}$.

These environmental conditions were prevalent during the end-Permian event (EPE), the largest mass extinction in Earth's history ${ }^{5}$. The EPE has been linked to a marked increase in global temperatures (increase of c. $6-12^{\circ} \mathrm{C}$ in the tropics ${ }^{6}$, c. $10-14^{\circ} \mathrm{C}$ at high southern latitudes ${ }^{7}$ ), and a rapid elevation of atmospheric $\mathrm{CO}_{2}$ (c. $600 \%$ in $\left.<75 \mathrm{Kyrs}\right)^{8}$, caused by massive magmatic outgassing from the Siberian Traps Large Igneous Province ${ }^{9}$. The most consequential long-term changes on land included the abrupt demise of wetland glossopterid forests of the temperate Southern Hemisphere ${ }^{10}$ and the tropical coal-forming forests of east Asia ${ }^{11}$. These were some of the most enduring and widespread biomes in Earth history, and their disappearance initiated a global "coal gap" in the rock record, reflecting a major reduction in atmospheric carbon drawdown that persisted for several million years ${ }^{12}$. Little is known of the subsequent continental recovery biomes for several reasons, including low ecosystem biomass, extensive oxidative weathering, and a scarcity of wellexposed, fossiliferous, non-marine strata of this age.

Long-term quantitative Permian and Triassic microbial records and algal concentrations from the continents are presently lacking, despite lakes and rivers being particularly susceptible to toxic microbial blooms, owing to their low turbulence, proximity to terrestrial nutrient sources, and long water residence times (e.g., in lowland lakes) ${ }^{1}$. A series of recent, high-precision age constraints $^{13-15}$, coupled with a well-resolved spore-pollen zonation scheme ${ }^{10,16}$, now crowns the Sydney Basin, Australia, as the standard reference succession for upper Permian and Lower Triassic continental fossil and rock unit correlations in the Southern Hemisphere. These strata provide a near-continuous record of coastal plain environments through the EPE ${ }^{13,14,16,17}$ (c. 252.2 $\mathrm{Ma}^{14}$ ), and span $>4$ Myrs of the post-EPE recovery interval $^{10,15}$ (Fig. 1). Here we present long-term, quantitative organic microfossil, sedimentary, and geochemical records of the Permian-Triassic transition from five stratigraphic sections in the Sydney Basin (Fig. 2 and Supplementary Data 1-16, Supplementary Figs. 1-6). The sections are tied to the regional biostratigraphic scheme ${ }^{10}$ (see "Methods" section) and the results are integrated with previous palynological studies across eastern Gondwana. These successions reveal that the lowlands of eastern Gondwana provided long-term refugia for thriving algal and bacterial communities after the collapse of late Permian plant biotas. We propose that the proliferation of microbial communities was both a symptom of continental ecosystem collapse, and a cause of its delayed recovery.

\section{Results}

The organic microfossil assemblages ("palynofacies"; Supplementary Data 1-4) define four successive ecological phases (see "Methods" section). Non-metric multidimensional scaling (nMDS) of the palynofacies supports these phases as indicated by their discrete regions in ordination space (Fig. 3).

Pre-EPE (pre-252.2 Ma): Late Permian wetland communities and ecosystem collapse. The "pre-EPE" phase is dominated by abundant wood, leaves, and pollen typical of wetland glossopterid gymnosperms (Fig. 2). Various other seed plants and diverse understorey ferns, sphenopsids, lycopsids, and bryophytes are also present, but are relatively less abundant. Algal diversity is relatively high, incorporating various chlorophyte green algae (e.g., Cymatiosphaera, leiosphaerids) and charophyte conjugating green algae (Zygnematophyceae; e.g., Ovoidites, Peltacystia, Tetraporina), but algal concentration values $\left(C_{\mathrm{a}}\right)$ are low (mean: $\leq 300$ fossils/g), and abundances of other microbial remains (represented by amorphous organic matter; AOM) are very low (mean: c. $5 \%$; Fig. 2). The $\mathrm{C}_{\text {org }} / \mathrm{N}_{\text {total }}$ is consistently high (Bootleg-8: mean $=15.73$, s.d. $=9.5$; Bunnerong- 1 : mean $=14.9$, s.d. = 8.4), reflecting abundant organic remains derived from $\mathrm{C}_{3}$ photosynthesis, the dominant metabolic pathway of land plants ${ }^{18}$. Pre-EPE coals and shales are typical of mires or well-vegetated river and coastal floodbasins ${ }^{14}$ and contain abundant trace fossils of grazers and other primary consumers. Collectively, the fossil and geochemical data indicate that highly productive forest-mire ecosystems dominated the humid coastal plains of the Sydney Basin prior to the EPE (Fig. 4).

The widespread collapse of the late Permian southern highlatitude land and freshwater biomes (the glossopterid flora ${ }^{10}$ and the Peltacystia Microalgal Province ${ }^{19}$, respectively), occurred at $\mathrm{c}$. $252.2 \mathrm{Ma}^{13,14}$ driven largely by warming and increased seasonality in precipitation ${ }^{13}$ (Fig. 4).

Early post-EPE (252.2-251.5 Ma): The microbial rising from the "dead zone". In all successions examined, the ensuing "early post-EPE" interval (Fig. 2) initiates with sedimentary rocks typical of shallow standing water, and depauperate fossil assemblages of fungi, charcoal and other opaque wood fragments. This corresponds to the widely reported "dead zone" (sensu refs. 16,20, Fig. 2), an interval spanning several millennia during which widespread wildfires and deforestation ${ }^{11,16}$ led to floodbasin water-table rise and ponding ${ }^{14,16}$.

Our high-resolution analyses of post-EPE outcrop exposures reveal successive green algal associations as the first colonizers of continental environments following this "dead zone". The Frazer Beach succession expresses a major pulse of algal proliferation within the $12 \mathrm{~m}$ sampled interval (Fig. 2). This algal pulse initiated with a monotypic assemblage of smooth-walled "leiosphaerids" (Leiosphaeridia), a group that likely represents chlorophyte algae in the Sydney Basin (see Discussion) ${ }^{19}$. This was followed by two peaks of algal concentrations $(61,000$ and 70,000 fossils/g), which were dominated by zygnematophycean charophytes (Circulisporites and Ovoidites, both groups with $>20,000$ fossils/g each), but with leiosphaerid algae abundances remaining high ( $>10,000$ fossils/g). Low concentrations of other chlorophyte groups (Pediastrum, Quadrisporites) were also recorded. Throughout this interval $(0-160 \mathrm{~cm})$, the Frazer Beach succession was deposited in very low salinity conditions (mean $\mathrm{Sr} / \mathrm{Ba}$ mean $=0.06$, s.d. $=0.05$ ). The algal pulse terminates abruptly $160 \mathrm{~cm}$ above the EPE extinction horizon, replaced by high spore and pollen abundances through the succeeding $20 \mathrm{~cm}$, accompanying the first occurrence of identifiable leaf fossils ${ }^{16}$ (Fig. 2). Pollen typical of pre-EPE wetland floras ("glossopteridtype" herein) persist in low abundances for $>4$ million years after the dead zone; however, no post-EPE fossils can be definitively attributed to Glossopteris have yet been recovered from eastern Australia. Such pollen likely derives from alternative surviving groups of seed plants ${ }^{10}$ and/or have been reworked from underlying strata.

The bore-core successions show that, on a broader stratigraphic scale, recurrent algal blooms occurred across the entire basin throughout the first c. 100 kyrs following the EPE (Fig. 2). 


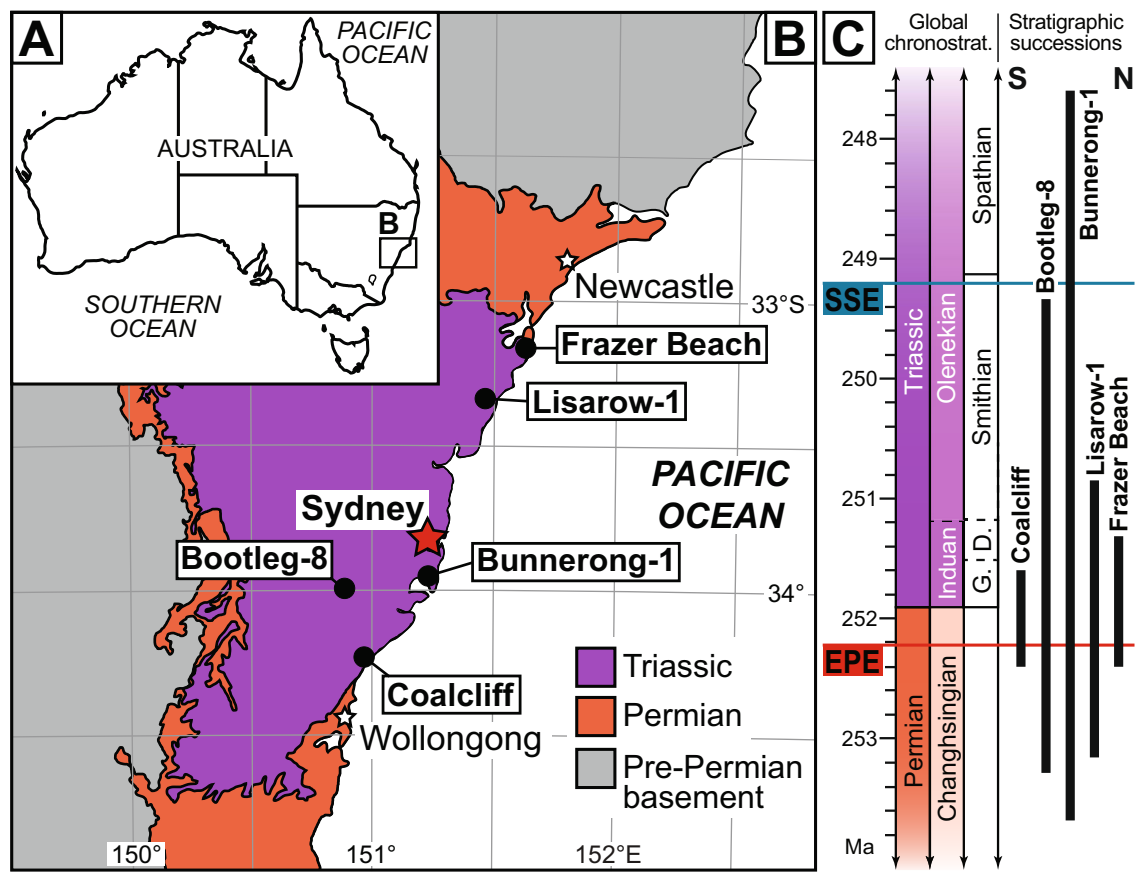

Fig. 1 Geologic map and stratigraphy of the Sydney Basin, Australia. A Map of modern Australia. B Geological map of southeastern Sydney Basin, with the locations of the studied core and outcrop successions. C Stratigraphic ranges of the examined Sydney Basin successions ${ }^{10,13,16}$ and correlation to the global upper Permian and Lower Triassic chronostratigraphy (chronostrat.) ${ }^{13-15}$; EPE = end-Permian extinction event, Ma = millions of years ago, SSE $=$ Smithian-Spathian climatic event, D. = Dienerian, G. = Griesbachian Stage, N = north, S = south.

In Bootleg-8 and Bunnerong-1, depositional conditions were fresh to brackish $(\mathrm{Sr} / \mathrm{Ba}$ : Bootleg- 8 mean $=0.11$, s.d. $=0.05$; Bunnerong- 1 mean $=0.4$, s.d. $=0.15)$ and algal assemblages were composed almost entirely of chlorophytes (leiosphaerids, Quadrisporites) at very high concentrations (Bootleg-8: 20,000-60,000 fossils/g). These values are consistent with blooms of chlorophyte algae within Quaternary freshwater/brackish lake sediments following local deforestation and/or enhanced nutrient influx ${ }^{21,22}$.

Coincident with the algal blooms, the early post-EPE interval of the Sydney Basin also featured abundance maxima of amorphous organic matter (AOM; Fig. 2). Modern photosynthetic bacteria, such as cyanobacteria, produce the same granular texture, filamentous structure, and strong fluorescence $e^{23,24}$ as the majority of AOM within this interval (Supplementary Fig. 4), indicating greatly enhanced rates of photosynthetic microbial productivity ${ }^{23}$. AOM abundances increased from pre-EPE levels of 2 or $11 \%$ to 33 or $41 \%$ during the early post-EPE phase (mean values from Bootleg- 8 and Lisarow-1, respectively). The post-EPE AOM abundances are extraordinarily high for oxygenated continental depositional environments of fresh- to brackish salinity $^{25}$ (Fig. 2). Since organic matter derived from freshwater algae and bacteria has relatively low $\mathrm{C}_{\text {org }} / \mathrm{N}_{\text {total }}$ values ${ }^{18}$, the severe reduction in $\mathrm{C}_{\text {org }} / \mathrm{N}_{\text {total }}$ values between the pre-EPE (Bootleg-8 and Bunnerong-1 combined mean $=15.3$, s.d. $=8.9$ ) to early post-EPE (mean $=7.0$, s.d. $=5.5$ ) intervals is consistent with elevated relative contributions by these microbial populations (Fig. 2). This relationship was supported herein by the negative correlations between $\mathrm{C}_{\text {org }} / \mathrm{N}_{\text {total }}$ and the abundances of AOM $(r=-0.4160, p=0.0345, N=26)$ and algae $(r=-0.7258$, $p=0.00003, N=26)$.

The early post-EPE phase saw greatly reduced evapotranspiration following the loss of wetland forests, with elevated water tables and inundation of the lowland floodplains by fresh- to brackish waters. Enhanced weathering intensity 7,13 and destabilization of soils following deforestation ${ }^{16,26}$, promoted nutrient influx into the floodbasins. Combined with elevated $\mathrm{CO}_{2}{ }^{6}$, temperature $^{6,7}$, and precipitation seasonality ${ }^{7,13}$, these factors promoted numerous intermittent pulses of algal and bacterial proliferation.

Late post-EPE (251.5-249.2 Ma): a recurrent microbial haven in the Early Triassic lowlands. Throughout this $>2.2 \mathrm{Myr}-$ interval $^{10,13,14}$, bacterial and algal abundances were generally high until at least the late Smithian (Fig. 2). Combined mean AOM from Bootleg- 8 and Lisarow- 1 was c. $20 \%$, and chlorophyte algal concentrations in Bootleg-8 were 5000-20,000 fossils/g. High algal and bacterial abundances are linked to consistently low $\mathrm{C}_{\mathrm{org}} /$ $\mathrm{N}_{\text {total }}$ values during the late post-EPE interval (Fig. 2), and algal (especially zygnematophycean charophyte) assemblages are of higher diversity compared to the previous phase. Sedimentary rocks of the coastal plain floodbasins contain abundant mudcracks and sparse trace fossils of benthic grazers (Fig. 4 and Supplementary Fig. 5). Sr/Ba ratios indicate consistently brackish or freshwater conditions in these temporary waterbodies.

Global $\mathrm{CO}_{2}$ and temperatures were high throughout most of this interval ${ }^{6-8}$, sustained by continued Siberian Traps magmatism until at least $250.60 \mathrm{Ma}$ (Smithian) ${ }^{27}$. During this time, eastern Gondwana (c. $65-75^{\circ} \mathrm{S}$ ) experienced strongly seasonal precipitation $^{7,13}$, and regular drying prevented the establishment of permanent wetland floras. delaying the return of high-latitude peat-mire carbon sinks until the Middle Triassic, prolonging the elevated global $\mathrm{CO}_{2}$ levels. The floras of this "coal gap"12 are represented by sparse leaf beds ${ }^{16}$ and soils with weakly developed roots and isoetalean rhizomorph horizons ${ }^{28}$, indicative of open, "dryland" (sclerophyll) forests of conifers, seed-ferns (Peltaspermales and Umkomasiales) and lycopsids ${ }^{10}$. Compared to pre-EPE wetland floras, the open post-EPE vegetation would have had relatively low biomass and evapotranspiration rates $^{29}$, facilitating seasonally high water tables and maximizing light availability to aquatic bacteria and algae $e^{30}$. Our combined data indicate that Dienerian-Smithian conditions were conducive to enduring 


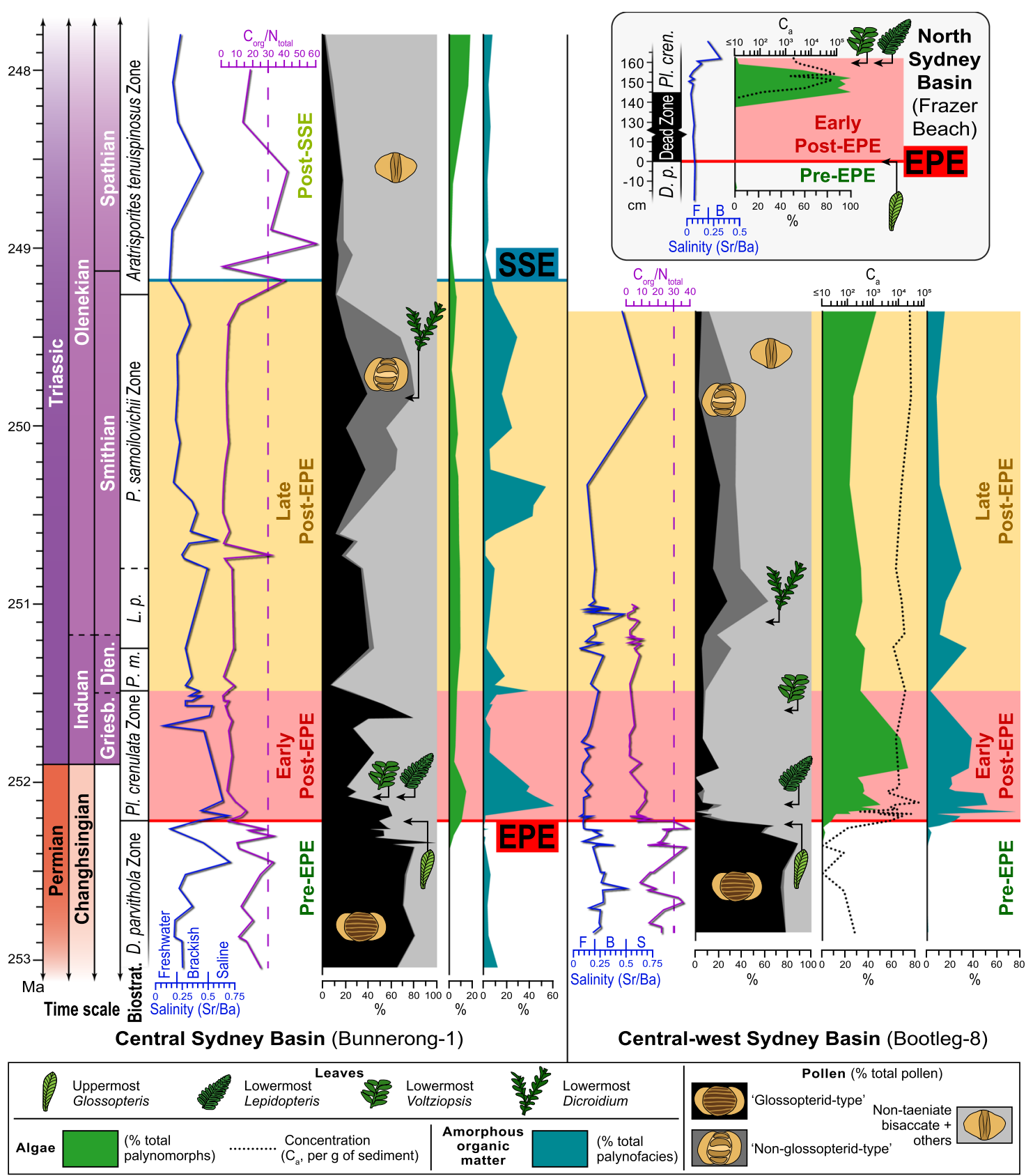

Fig. 2 Microfossil and geochemical trends from the upper Permian to Lower Triassic of the Sydney Basin, Australia. Data from Bootleg-8 and Bunnerong-1 are rescaled to the global chronostratigraphic scheme by anchoring spore-pollen biostratigraphic zone (biostrat.) boundaries to high-precision radiogenic isotope ages within the eastern Australian succession ${ }^{13-15}$ as calibrated in refs. ${ }^{10,14}$. Bunnerong-1 amorphous organic matter and algal data from ref. ${ }^{13}$. Salinity category values follow ref. ${ }^{82}$. B brackish, $F$ freshwater, $S$ saline. Dashed lines at $C_{\text {org }} / N_{\text {total }}=30$ for ease of comparison between successions. Note: glossopterid-type pollen were produced by both glossopterids and some other seed plants, "last Glossopteris" refers to leaf remains, not "glossopterid-type" pollen. "Dead zone" from ref. ${ }^{16}$, EPE = end-Permian extinction event, Ma = millions of years ago, SSE = Smithian-Spathian climatic event, D. = Dulhuntyispora, L. p. = Lunatisporites pellucidus Zone, P. m. = Protohaploxypinus microcorpus Zone, PI. = Playfordiaspora. Source data are provided as a Source Data file.

fresh/brackish-water ecosystems with sustained high abundances of algae and bacteria within fluctuating coastal plain waterbodies.

Post-SSE (249.2-? Ma): the end of the microbial regime. The first substantial changes in lowland ecosystems following the EPE occurred during the Smithian-Spathian event (SSE; c. 249.2 Ma). Regionally, this event was an interval of enhanced chemical weathering ${ }^{13}$ and ecological instability ${ }^{10}$. In Bunnerong-1, the SSE is concurrent with a marked reduction in algal and AOM abundances, while a general increase in $\mathrm{C}_{\text {org }} / \mathrm{N}_{\text {total }}$ values reflects a change in abundances from microbe-derived organic remains to those of land plants (Fig. 2). This concurs with global vegetation trends, characterized by widespread recovery of gymnosperm floras $^{10,31}$, promoted by climatic cooling 6 .

\section{Discussion}

Harmful microbial blooms across the post-extinction lowlands. Following the end-Permian extinction, high abundances of algae and bacteria were facilitated by recurrent, dysoxic, fresh to brackish waterbodies across the floodbasins for more than three 


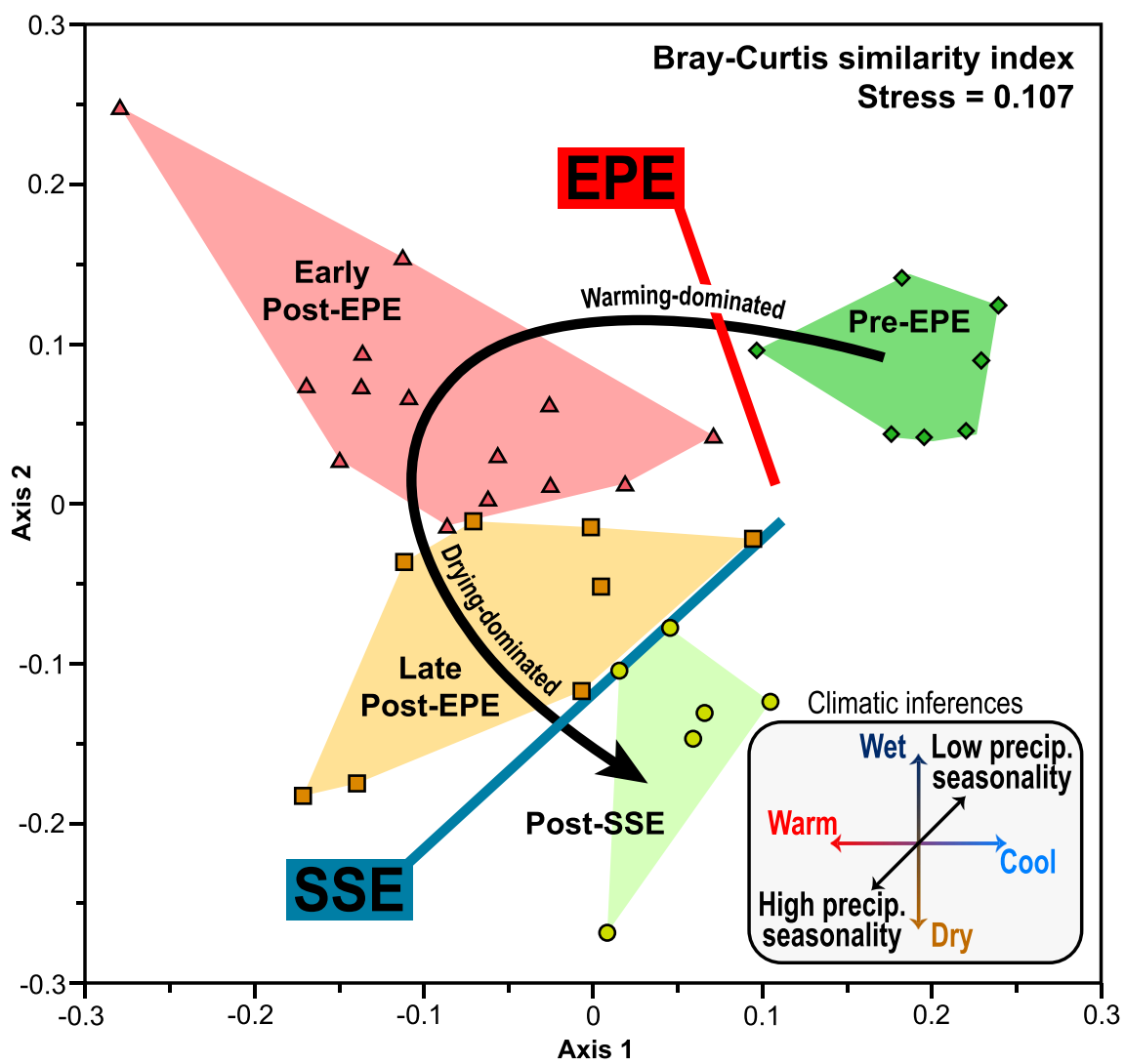

Fig. 3 Non-metric multidimensional scaling (nMDS) plot for the ecological phases of the Late Permian to Early Triassic, based on organic microfossil assemblages of the Sydney Basin, Australia. Insert box indicates inferred climatic changes through this interval, based on plant fossils, sedimentary features and climate modeling,12-14. Large arrow indicates the progression of phases in stratigraphic order; EPE = end-Permian extinction event, precip precipitation, SSE = Smithian-Spathian climatic event. Source data are provided as a Source Data file.

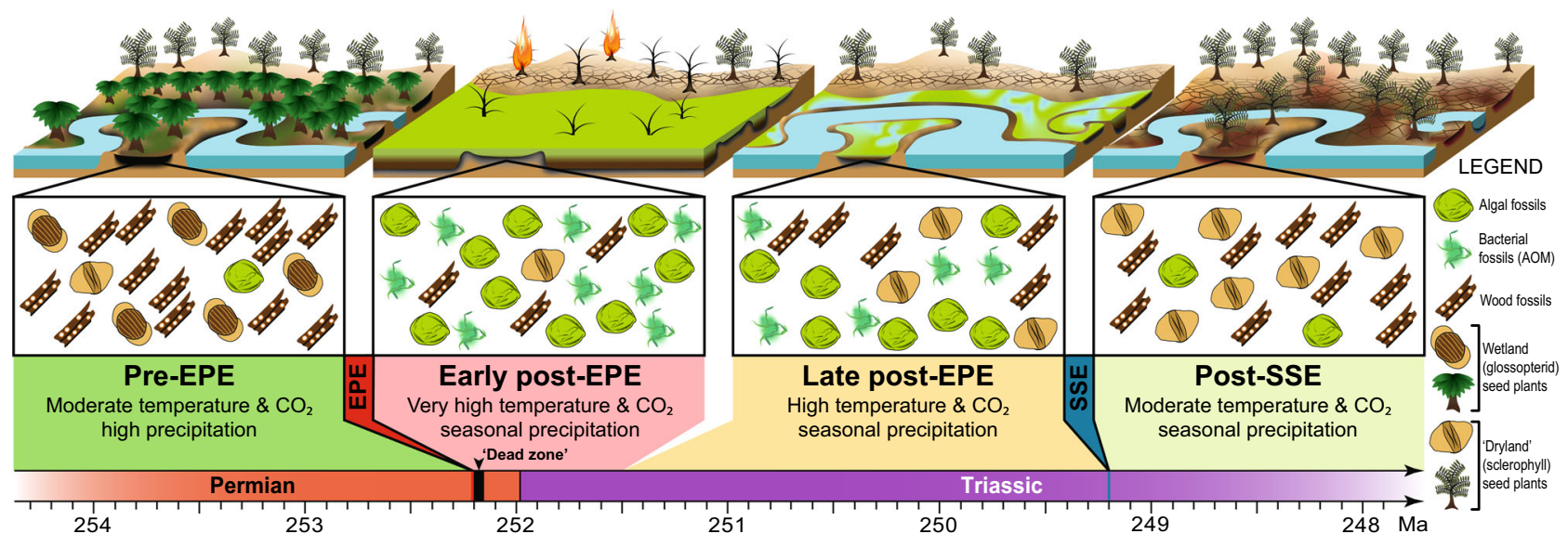

Fig. 4 Reconstructions of late Permian to Early Triassic continental ecological phases with representative organic microfossil assemblages. $\mathrm{AOM}=$ amorphous organic matter, $\mathrm{EPE}=$ end-Permian extinction event, Ma = millions of years ago, SSE = Smithian-Spathian climatic event.

million years (Figs. 2 and 4). For the early post-EPE, there is a strong negative correlation between algal abundance and salinity $(r=-0.6123, p=0.00089, N=26)$, and the highest algal abundances are evident within the lowest salinity regions of the Sydney Basin (e.g., Bootleg-8, FBO; Fig. 2). Chemically stable polymers have been widely reported within the cell walls ${ }^{32,33}$ of the nearest extant relatives of the Sydney Basin fossil algae ${ }^{19}$. Among extant algae, these polymers serve to prevent their desiccation while dormant in ephemeral waterbodies (e.g., lakes, ponds, streams) under seasonal climates ${ }^{34,35}$. Such conditions prevailed in the post-EPE lowlands across southern Gondwana ${ }^{14}$ and would have selectively promoted the proliferation of desiccation-resistant algae. The two most abundant algae (Leiosphaeridia, Quadrisporites) likely represent chlorophytes, based on morphological and architectural similarities to extant groups ${ }^{19}$. While Leiosphaeridia has a very long geological history and encompass groups of disparate relationships, the two alternative affinities for continental representatives of this genus from the Permian and Triassic (Trebouxiophyceae, prasinophytes ${ }^{19}$ ) are both chlorophytic $^{36}$. In the early post-EPE interval, high abundances of other freshwater green algae (Zygnematophyceae: Circulisporites, Ovoidites) occurred within the area of lowest salinity (FBO; 


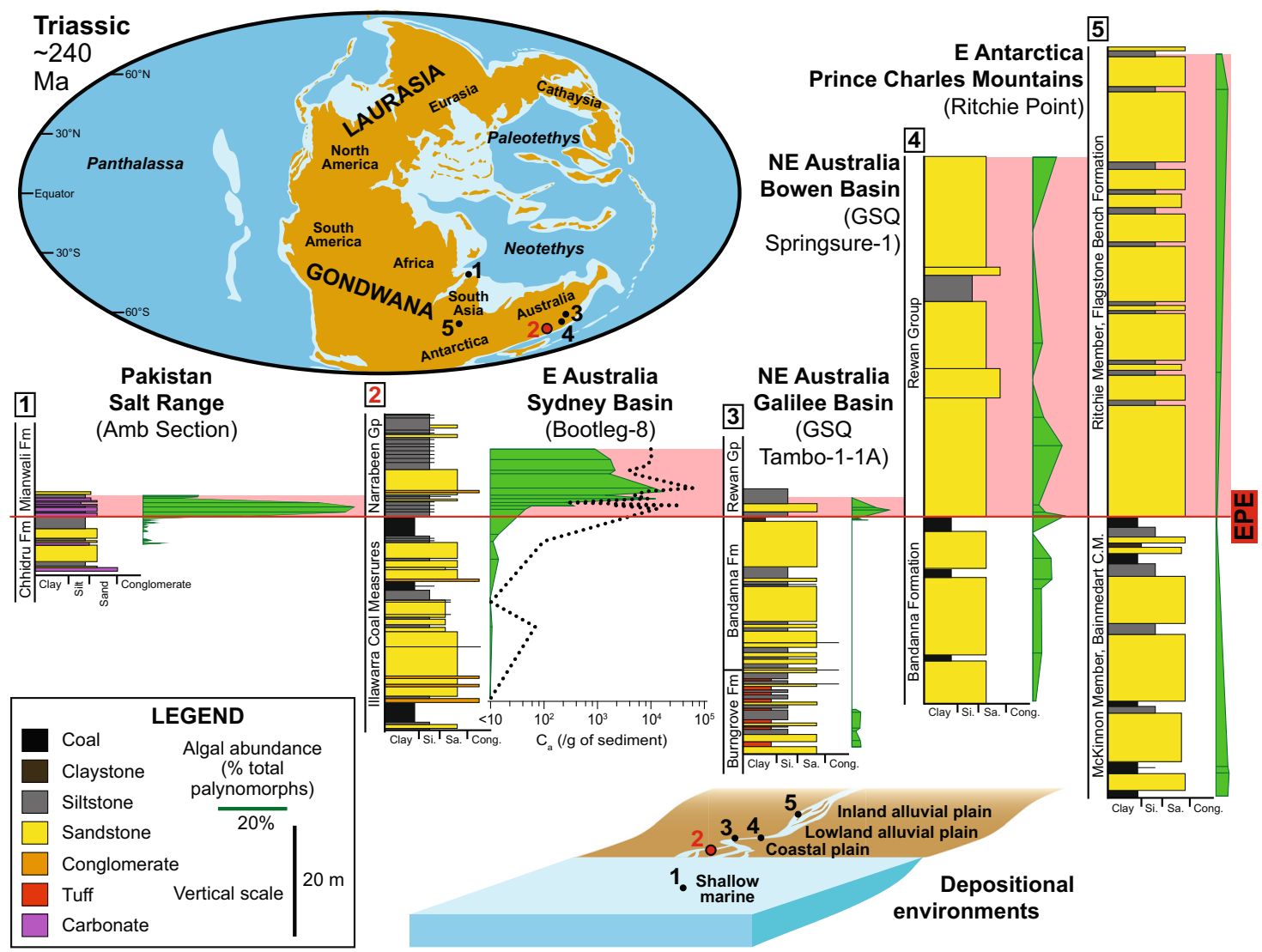

Fig. 5 Gondwanan algae abundances across the end-Permian extinction event (EPE). Triassic paleographic map indicates the Gondwanan localities compared here; map modified from ref. ${ }^{84}$. Relative abundances of algae are highest at, or soon after, the EPE at all Gondwanan sites. The exception is in the Prince Charles Mountains (PCMs) where sampling may be too sparse and sediment reworking has degraded the post-extinction microfossil signal. Relative abundances of algae are higher with decreasing depositional relief. Data sources (left to right): Salt Range ${ }^{50}$, Sydney Basin (this study), Galilee Basin ${ }^{37}$, Bowen Basin $44, P C M s{ }^{45} . C_{a}=$ algal concentration, C.M. $=$ Coal Measures, EPE $=$ end-Permian extinction event, Ma $=$ millions of years ago. Source data are provided as a Source Data file.

Fig. 2), but the proportion of non-chlorophytes is generally low across the Sydney Basin, and in continental deposits elsewhere ${ }^{37}$. High chlorophyte abundances in the post-EPE lowlands can be attributed to their tendency to proliferate in warm ${ }^{3}$, nutrient-rich environments ${ }^{38}$ and their competitive advantage under high $\mathrm{CO}_{2}$ levels ${ }^{39}$. The dominance of this group over other groups (e.g., Zygnematophyceae) is likely due, in part, to their relative tolerance of brackish waters ${ }^{19,40}$.

Owing to their propensity to decompose in oxygenated water $^{24,25}$, accumulations of cyanobacteria and other microbes were favored by low dissolved oxygen concentrations in the postEPE floodbasins. This is supported by the scarcity of invertebrate animal trace fossils from this interval of the Sydney Basin ${ }^{14}$ and other continental basins ${ }^{41,42}$. This also indicates the reduction of aquatic invertebrates through the EPE that would otherwise have prevented the preservation of abundant microbial remains via predation, detritivory, and sediment oxidation. Many of the conditions that promoted chlorophyte blooms in this interval (high $\mathrm{CO}_{2}$, temperature, nutrient influx) similarly favor harmful cyanobacterial blooms in modern freshwater settings ${ }^{1,2}$. The optimal growth temperature range for both chlorophytes and harmful cyanobacteria in freshwater environments is c. $20-32{ }^{\circ} \mathrm{C}^{1,3}$, which matches the estimated continental summer surface air temperatures (CSSATs) of eastern Gondwana for the earliest Triassic 7,13 , and is within the range of projected midlatitude CSSATs for the year $2100^{43}$. Bacterial and algal blooms in these intermittent waterbodies would have contributed to dysoxia and likely produced secondary metabolites toxic to animals ${ }^{1}$, impeding the recovery of Early Triassic freshwater ecosystems for at least 100 kyrs during this interval of recurrent microbial blooms.

In modern freshwater and marine environments, such blooms are considered a major threat to future ecosystem stability ${ }^{2}$. Our findings from the deep geological record underscore these warnings, and provide a disturbing prediction for the long-term consequences of continued warming and deforestation.

Connecting and contrasting the end-Permian oceanic and continental records. Comparison of the early post-EPE algal blooms of the Sydney Basin with other localities across the Gondwana supercontinent (Fig. 5) reveals concurrent relative abundance spikes of algae (and probable algal "acritarchs"; see "Methods" section). Continental successions spanning the EPE generally host higher relative abundances of fossil algae remains in more distal fluvio-lacustrine settings ${ }^{37,44-46}$ (Fig. 5), highlighting improved opportunities for preservation in sluggish waterways (e.g., coastal plains). Higher energy fluvial settings, e.g., in the Permian-Triassic rift valley systems of central India ${ }^{47}$ and East Antarctica ${ }^{45}$, were less conducive to the preservation of extensive floodbasin deposits and accumulations of green algae, and more prone to sediment reworking, resulting in subdued algal abundances.

In marine settings, bacterial (including cyanobacterial) communities thrived in the aftermath of the EPE ${ }^{48,49}$. Similarly, marine algae experienced a near-global abundance "spike"50-54 in strata immediately succeeding the EPE (Fig. 5); over the long- 


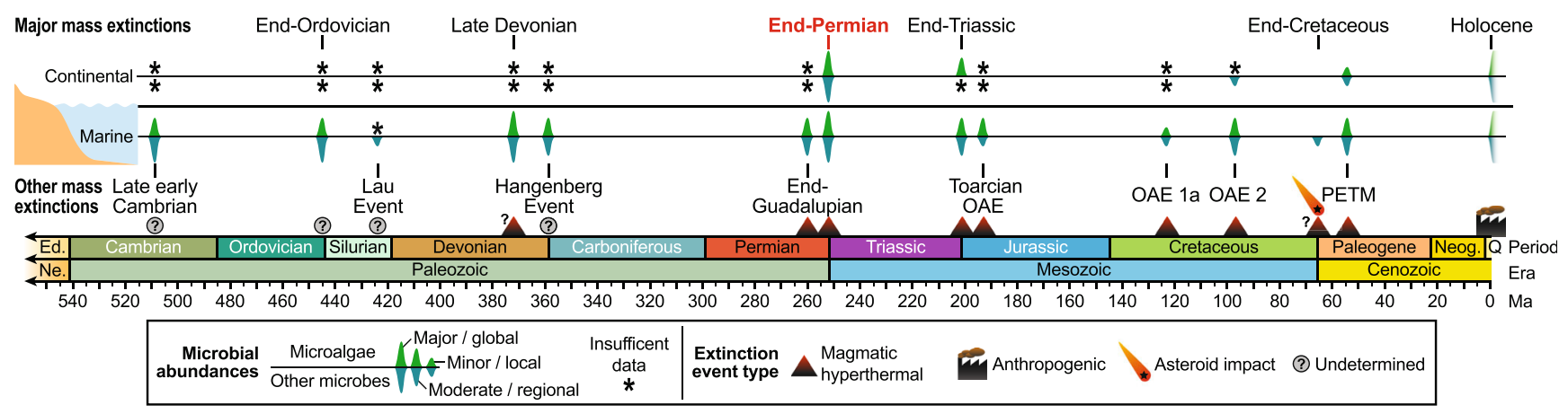

Fig. 6 Phanerozoic mass extinctions with evidence of increased microbial abundances. Inferred minor/local or moderate/regional microbial abundances

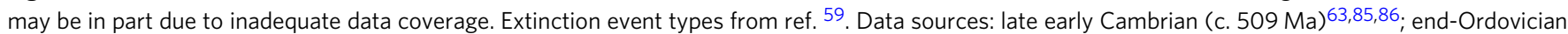
(c. 445 Ma)63,87; Lau Event (c. 424 Ma)64; Late Devonian (c. 372 Ma)62,63; Hangenberg Event (c. 359 Ma)62,63; end-Guadalupian (c. 260 Ma)19,88; endPermian (c. $252 \mathrm{Ma}$ ) 10,16,37,44,47,49-54,63,89; end-Triassic (c. 183 Ma)60,64,90-92; Toarcian oceanic anoxic event (c. 183 Ma) $93-95$; Cretaceous OAE 1a (c. $123 \mathrm{Ma}$ )96; Cretaceous OAE 2 (c. $94 \mathrm{Ma}$ )96-102; end-Cretaceous (c. $66 \mathrm{Ma}$ )62,63,69,70,103-105; Paleocene-Eocene Thermal Maximum (c. 56 Ma)61,106-109; Holocene ${ }^{1,2,110,111}$. Ed. $=$ Ediacaran, $\mathrm{Ma}=$ millions of years ago, Ne. $=$ Neoproterozoic, Neog. $=$ Neogene, OAE $=$ oceanic anoxic event, PETM = PaleoceneEocene thermal maximum, $\mathrm{Q}=$ Quaternary.

term, however, marine algal concentrations decreased ${ }^{51,55}$, suggesting an overall reduction in primary productivity ${ }^{56}$. The initial post-EPE increase of algae in nearshore environments has been interpreted as an in situ bloom linked to decreased salinity due to enhanced input of freshwater ${ }^{57}$ and/or soil nutrient ${ }^{58}$. However, the most common algae in several coeval shallow marine records ${ }^{50,51,55}$ are similar to the primary constituents of the continental Sydney Basin algal assemblages (e.g., Leiosphaeridia) suggesting that algae from freshwater blooms were transported to the marine realm en masse. Without accounting for this, productivity will be overestimated if based solely on early post-EPE shallow marine algal fossils.

Extinction events and anachronistic freshwater ecosystems. Magmatically triggered "hyperthermal" climates, characterized by very rapid increases in temperature and atmospheric $\mathrm{CO}_{2}$, have been causally linked to most mass extinctions (e.g., EPE, endTriassic event $[\mathrm{ETE}])$ and numerous other biotic turnover events (e.g., Paleocene-Eocene Thermal Maximum [PETM] $)^{59}$. Microbedominated fossil assemblages have been widely reported from the marine records of hyperthermal events, but only rarely from continental successions, largely owing to the scarcity of studies (Fig. 6). Where documented, the continental assemblages of other rapid warming events reveal remarkably similar algal and bacterial increases to those of the post-EPE interval of the Sydney Basin. These include anomalously high abundances of leiosphaerids ${ }^{60,61}$, other freshwater algae $\left(\mathrm{ETE}^{60}\right)$, and/or AOM $\left(\mathrm{PETM}^{61}\right)$. However, these latter events express microbial increases of lower magnitudes and shorter durations than those reported herein, likely owing to the less severe climatic shifts and the relatively modest continental ecosystem changes. Microbial proliferation during post-extinction intervals was largely a result of the significant reduction in other organisms that would normally consume, outcompete, or otherwise suppress the microbial populations ${ }^{62-64}$. In turn, we propose that recurrent microbial proliferation events likely hindered freshwater ecosystem recovery for most extinction events of the last several hundred million years.

An exception to this pattern is the end-Cretaceous extinction event (c. $66 \mathrm{Ma}$ ), which eliminated numerous large vertebrate clades, including the non-avian dinosaurs. This event was concurrent with, or immediately preceded by, a major episode of magmatism (the Deccan Traps Large Igneous Province), and an interval of associated warming ${ }^{65}$. Although this magmatism may have contributed to the biotic turnover, the majority of extinctions are attributable to a very large asteroid impact ${ }^{66}$, which injected voluminous dust and sulfate aerosols into the atmosphere, reducing incident solar radiation 67 and severely limiting marine microbial productivity ${ }^{68}$. Once light levels returned to pre-extinction levels, microbes underwent a shortlived, global proliferation ${ }^{69}$, especially proximal to the impact site $^{70}$. However, compared to other extinction events, this pulse was relatively minor and brief ${ }^{62}$, probably due to the modest long-term increase in atmospheric $\mathrm{CO}_{2}$ and temperature ${ }^{71}$. The contrasting microfossil signals for hyperthermal and asteroid impact events likely indicate the importance of sustained elevated greenhouse gas levels for the promotion of recurrent, harmful algal and bacterial blooms.

Post-EPE organic microfossil assemblages of the Sydney Basin resemble some of the earliest known continental ecosystems on Earth. Organically preserved fossils from the lake deposits of the Nonesuch Formation, USA (c. 1083-1070 Ma), reveal thriving communities of photosynthetic (cyano)bacteria, and eukaryotic assemblages dominated by Leiosphaeridia ${ }^{72}$. Although the specific organisms are unlikely to be closely related (e.g., Leiosphaeridia is polyphyletic ${ }^{19}$ ), the Sydney Basin post-EPE pulse of similar algae and cyanobacteria seems starkly anachronistic. "Anachronistic facies", typically represented by microbial communities preserved as inorganic sedimentary structures (microbialites) ${ }^{63}$, have long been known to characterize post-EPE marine ${ }^{73}$, and some continental, strata ${ }^{41}$. However, the present assemblages represent the first recorded organically preserved anachronistic communities in continental waterways following the EPE.

Continental ecosystem collapse paved the way for flourishing freshwater algal and bacterial communities in the wake of the largest mass extinction in Earth history: the end-Permian event (c. $252.2 \mathrm{Ma}$ ). Within the following c. $100 \mathrm{kyrs}$, prolific bacterial remains, and several pulses of high algal concentrations are evident in continental strata of the Sydney Basin, and in coeval lowland and shallow marine deposits across the Gondwanan supercontinent. Microbial proliferation was caused by the loss of lowland vegetation, which promoted high water tables, nutrient influx into waterways, and was intensified by extremely high $\mathrm{CO}_{2}$ and temperature. Although a new flora appeared soon after ecosystem collapse, dense forest vegetation was absent for $>3$ Myrs, and lowland landscapes were regularly inundated by ephemeral, stagnant, fresh/brackish waterbodies hosting thriving algal and bacterial populations. Seasonal drought precluded the formation of peat-forming wetland mires, thus preventing the re- 
establishment of these major carbon sinks during the Early Triassic, while microbe-derived toxins and dysoxia likely delayed the recovery of freshwater faunas. We highlight similarities of these microbial communities to some of the oldest known freshwater ecosystems, and postulate that such anachronistic continental fossil assemblages are symptomatic of major disruptions in freshwater ecosystems. Although continental records are sparse, Earth's global warming-driven extinction episodes are consistently linked to the proliferation of freshwater microbes, indicating that this is a recurrent phenomenon, and represents a disconcerting signal for future environmental change. These findings demonstrate the enduring deleterious impacts on continental biotas of climate-driven deforestation and prolonged high atmospheric greenhouse gas concentrations.

\section{Methods}

All data derived from stratigraphic successions within the Sydney Basin, Australia (Fig. 1); new data were collected from 1, Australian Gas Light Company Bootleg DDH 8 (Bootleg-8); 2, Elecom Hawkesbury Lisarow DDH 1 (Lisarow-1); 3, Coalcliff outcrop (CCO); 4, Pacific Power Hawkesbury Bunnerong DDH 1 (Bunnerong-1); and 5, Frazer Beach outcrop (FBO; Supplementary Data 1-16).

Palynology. One hundred and fifty palynological samples were analyzed; 31 samples from Bootleg-8, 27 samples from Lisarow-1, 14 samples from CCO, 24 samples from Bunnerong-1, and 54 samples from FBO (Supplementary Data 1-11). Taxonomic categories are outlined in Supp. Data 12. Spore-pollen biostratigraphic zones and regional correlations follow ref. ${ }^{10}$. Palynological samples are housed at the Department of Palaeobiology, Swedish Museum of Natural History, Stockholm, Sweden.

To ensure the validity of inter-sample comparisons, all but two palynological samples (S029743, S029758) were collected from siltstone/claystone, heterolithic (interlaminated siltstone-fine sandstone), or coal lithofacies. These correspond to facies associations $\mathrm{E}, \mathrm{F}, \mathrm{G}$, or $\mathrm{H}$ of ref. ${ }^{14}$, interpreted as alluvial/coastal plain floodbasin $(\mathrm{E}, \mathrm{F})$, lake $(\mathrm{G})$, or mire $(\mathrm{H})$ palaeoenvironments. Palynological samples were digested using hydrochloric and hydrofluoric acids to remove inorganic mineral content. Quantitative analyses of samples from Bootleg-8, CCO, Lisarow-1, and $\mathrm{FBO}$ were undertaken via kerogen-based palynofacies abundance counts of $\geq 300$ (FBO) or $\geq 500$ (Bootleg-8, CCO, Lisarow-1) individual grains where possible (see Supplementary Data 1-4 for specimen categories). Bootleg-8, CCO, FBO, and Bunnerong- 1 residues were oxidized with Schulze's Solution and sieved (Bootleg- 8 and FBO: $5 \mu \mathrm{m}$; CCO and Bunnerong-1: $10 \mu \mathrm{m}$ ), followed by palynomorph counts of $\geq 100$ specimens (FBO) or $\geq 250$ (Bootleg-8, CCO, Bunnerong-1) where possible (Supplementary Data 5-11). Palynomorph concentrations and index taxon data were derived from slides that underwent this process (Supplementary Data 5-7) Light microscopy and photomicrography of fossil specimens were conducted using either a Zeiss Axioskop 2 Plus transmitted light microscope equipped with a Zeiss AxioCam MRc camera, or an Olympus BX51 transmitted light microscope equipped with a Lumenera Infinity 2 digital camera. AOM was categorized using standard light and fluorescence microscopy ${ }^{24}$. Fluorescence microscopy employed an Olympus BX51 equipped with an Olympus U-RFL-T fluorescence source (460-490 nm blue light excitation ${ }^{74}$ ) and an Olympus DP72 camera. All fluorescence photomicrographs were taken with $200 \mathrm{~ms}$ exposure lengths and ISO 200.

Concentration estimates were conducted using Lycopodium tablets from batches \#3862 (Bootleg-8 and FBO [in part]), \#140119321 (CCO), or \#124961 (FBO [in part]), prepared by the Department of Geology, Lund University. Palynomorph concentration per gram of dried sediment $\left(C_{\mathrm{p}}\right)$ is derived by the following calculation (modified from ref. ${ }^{75}$ ):

$$
C_{\mathrm{p}}=\left(N \times t \times L_{\mathrm{t}}\right) /(L \times M),
$$

where $N=$ total palynomorph sample count, $t=$ number of Lycopodium tablets, $L_{\mathrm{t}}=$ estimated Lycopodium spores per tablet $\left(L_{\mathrm{t}}\right.$ for Bootleg- 8 and FBO [in part $]=9666$, standard deviation [s.d.] $=671 ; L_{\mathrm{t}}$ for $\mathrm{CCO}=19855$, s.d. $=521 ; L_{\mathrm{t}}$ for $\mathrm{FBO}$ [in part] $=12542$, s.d. $=931$; see ref. $\left.{ }^{76}\right), L=$ Lycopodium spores counted, and $M=$ mass of dried sediment. Algal concentration per gram of dried sediment $\left(C_{\mathrm{a}}\right)$ is calculated by:

$$
C_{\mathrm{a}}=(\mathrm{a} / N) \times C_{\mathrm{p}},
$$

where $a=$ total count of algae ( + acritarchs). Concentration estimates assume the minimal loss of palynomorphs or algal cysts during sample processing (including $\mathrm{HF}$ - and $\mathrm{HCl}$-acid maceration, oxidation, and sieving) sample counts. Sample counts where no Lycopodium were encountered were excluded from estimates and illustrations since reliable concentration values could not be calculated. To standardize pre-burial biases, only samples from mudstone (claystone or siltstone) lithofacies were included in the illustrations.
Phylogeny and terminology. Algae (sensu lato) is an informal, polyphyletic group encompassing a broad range of photosynthetic eukaryotes, including evolutionarily disparate lineages such as Chromista (e.g., dinoflagellates) and the paraphyletic "green algae", which consists of all green plants (Viridiplantae) sans land plants ${ }^{77}$ Many of the fossils we report herein fall under the definition of "acritarch" outlined in ref. ${ }^{78}$, which includes any small organic-walled fossil of unknown affinity. However, with the possible exception of Reduviasporonites ${ }^{79}$, all of these have probable affinities to algae (s.l. $)^{19}$; hence, we have generally included all such fossils under the term "algae" for concision. Unless specified, "algae" always refers to microscopic algae (or "microalgae"). Phylogeny of extant green algae follows ref. 36

Microbe (adjective: microbial) fossils refer to the remains of any organism that can only be seen under a microscope; in the present study, this includes fossils of bacteria, microalgae, and acritarchs (N.B. excluding land plant remains, such as spores, pollen and wood/leaf fragments).

We use the term "palynofacies" in its originally defined sense ${ }^{80}$ to refer to the total assemblage of hydrochloric- and hydrofluoric-acid insoluble organic remains of sediment or sedimentary rock sample.

Ordination analysis. Palynofacies assemblages were categorized by ecological phases, based primarily on the chemostratigraphy, biostratigraphy and palynofloral intervals of an earlier study ${ }^{10}$; these were (in stratigraphic order): 1, pre-EPE (=Dulhuntyispora parvithola Spore-pollen Zone); 2, early post-EPE (=Playfordiaspora crenulata Spore-pollen Zone, plus the "dead zone" sensu refs. ${ }^{3,16}$ ), late post-EPE (=Protohaploxypinus microcorpus Spore-pollen Zone to the $\delta^{13} \mathrm{C}_{\text {org }}$ excursion that marks the SSE ${ }^{10,31}$, which corresponds to the lower A. tenuispinosus Spore-pollen Zone); and 4, post-SSE (=lower to mid-A. tenuispinosus Spore-pollen Zone). To test the validity of these time bins as discrete ecological phases, nMDS was employed on the palynofacies abundance data. Ordination analysis was conducted with the program PAST (v.4.03 ${ }^{81}$ ).

To control for local variations in depositional conditions, all samples were from: 1 , siltstone/claystone or heterolithic lithofacies; and 2, a single stratigraphic succession (Bootleg-8), except for the post-SSE population, since this interval only available from Bunnerong-1. A total of 35 assemblages met these selection criteria. The Bray-Curtis (dis)similarity index was derived for estimating the differences between palynofacies assemblages; prior to analysis, data were treated with square root transformations to constrain the palynomorph abundance ranges while preserving their rank-orders, and to facilitate direct comparisons with the previous analyses ${ }^{10}$.

Sedimentology. Bore cores and surface exposures were logged sedimentologically, and successions were subjected to a facies analysis that is fully reported in ref. ${ }^{14}$ Facies associations were defined on the basis of lithology, nature of bed contacts, bed geometry (for outcrops), preserved physical and biogenic structures, color, associated fossils (including ichnofossils), and any other pertinent characteristics (see Table 1 of ref. ${ }^{14}$ ).

Geochemistry. The stable carbon isotope composition of bulk organic matter $\left(\delta^{13} \mathrm{C}_{\text {org }}\right)$ was determined on splits of samples used for palynological analysis in cores Bootleg- 8 and Bunnerong-1. Total organic carbon $\left(\mathrm{C}_{\text {org }}\right)$, total nitrogen $\left(\mathrm{N}_{\text {total }}\right)$, and $\delta^{15} \mathrm{~N}$ values (not reported here) were measured simultaneously. In preparation for analysis, up to $500 \mathrm{mg}$ of powdered sample was placed in a $50 \mathrm{ml}$ centrifuge tube and reacted overnight with $1 \mathrm{~N} \mathrm{HCl}$ at room temperature to remove carbonate mineral phases. Samples were then rinsed three times with ultra-pure water, with the supernatant separated by centrifugation $(950 \times g$ for five minutes) and discarded. Samples were subsequently dried and crushed using an agate mortar and pestle. Samples were analyzed using a Costech Elemental Analyzer connected to a Thermo Finnigan MAT 253 stable-isotope gas-ratio mass spectrometer at the Keck-NSF Paleoenvironmental and Environmental Laboratory, University of Kansas, USA. Carbon isotope compositions are reported in per mil (\%o) relative to the Vienna Peedee Belemnite (V-PDB) standard. Montana Soil (NIST Ref. Mat. 2711) and a calibrated yeast standard were used to monitor quality control, with compiled results over two years showing analytical error to be within $\pm 0.22 \%$ o for $\delta^{13} \mathrm{C}_{\text {org }}$ values. Reproducibility of $\mathrm{C}_{\text {org }}$ and $\mathrm{N}_{\text {total }}$ analyses were monitored through replicate analyses of adenosine triphosphate (approximately one standard analysis for every 10 samples). Results indicate that reproducibility is better than \pm 0.09 and \pm 0.04 wt $\%$ for $\mathrm{C}_{\text {org }}$ and $\mathrm{N}_{\text {total }}$, respectively.

To aid in discriminating between fresh, brackish, and saline facies, the $\mathrm{Sr} / \mathrm{Ba}$ paleosalinity proxy, proposed and tested in ref. ${ }^{82}$, was applied to splits of $\mathrm{CaCO}_{3}$ poor, mud-grade samples. In modern sediments collected from a range of settings, these authors ${ }^{82}$ distinguished between facies deposited within freshwater $(\mathrm{Sr} / \mathrm{Ba}$ : $<0.2$ ), brackish ( $\mathrm{Sr} / \mathrm{Ba}: 0.2-0.5)$ and marine/saline $(\mathrm{Sr} / \mathrm{Ba}:>0.5)$ environments, with a prediction accuracy of c. $66 \%$. Sr and Ba concentrations were determined using a Bruker Tracer 5i portable X-ray fluorescence (XRF) analyzer in the Sedimentary Geochemistry Laboratory, University of Nebraska-Lincoln, USA. The instrument was calibrated with a series of mudrock standards that include a suite of reference materials characterized by ref. ${ }^{83}$ and nine in-house reference materials from Permo-Triassic mudrocks in Bunnerong- $1^{13}$. Ba concentrations were analyzed with no filter at $15 \mathrm{kV}$ and $15 \mu \mathrm{A}$ and a count time of $30 \mathrm{~s}$, with one analysis measured under a helium flush to negate atmospheric interference. Sr concentrations were determined at $50 \mathrm{kV}$ and $35 \mu \mathrm{A}$ and a count time of $30 \mathrm{~s}$, with a $\mathrm{Cu} 100 \mu \mathrm{m}: \mathrm{Ti}$ 
$25 \mu \mathrm{m}: \mathrm{Al} 200 \mu \mathrm{m}$ filter. For all analyses, the raw count rate per second (rcps) signals lay between 20,000 and 100,000 rcps. Reproducibility of Sr and Ba analyses was monitored through replicate analysis of samples, at a rate of approximately one replicate analysis per 20 samples. Results indicate that reproducibility is $\pm 5 \mathrm{ppm}$ for $\mathrm{Sr}$ and $\pm 124 \mathrm{ppm}$ for $\mathrm{Ba}$.

Statistical correlations between coeval palynological and geochemical samples employed the Pearson correlation coefficient (Pearson's $r$ ), and statistical significance $p$ values (two-tailed) were calculated for each. Full correlation statistics are provided in Supplementary Data 16.

Reporting summary. Further information on research design is available in the Nature Research Reporting Summary linked to this article.

\section{Data availability}

All data generated or analyzed during this study are included in this published article (and its Supplementary Information files). Source data are provided with this paper.

Received: 12 February 2021; Accepted: 25 August 2021;

Published online: 17 September 2021

\section{References}

1. Paerl, H. W. \& Otten, T. G. Harmful cyanobacterial blooms: causes, consequences, and controls. Microb. Ecol. 65, 995-1010 (2013).

2. Visser, P. M. et al. How rising $\mathrm{CO}_{2}$ and global warming may stimulate harmful cyanobacterial blooms. Harmful Algae 54, 145-159 (2016).

3. Lürling, M., Mendes e Mello, M., van Oosterhout, F., de Senerpont Domis, L. \& Marinho, M. M. Response of natural cyanobacteria and algae assemblages to a nutrient pulse and elevated temperature. Front. Microbiol. 9, 1851 (2018).

4. Low-Décarie, E., Fussmann, G. F. \& Bell, G. Aquatic primary production in a high- $\mathrm{CO}_{2}$ world. Trends Ecol. Evol. 29, 223-232 (2014).

5. Stanley, S. M. Estimates of the magnitudes of major marine mass extinctions in earth history. PNAS 113, E6325-E6334 (2016).

6. Sun, Y. D. et al. Lethally hot temperatures during the Early Triassic Greenhouse. Science 338, 366-370 (2012).

7. Frank, T. D. et al. Pace, magnitude, and nature of terrestrial climate change through the end Permian extinction in southeastern Gondwana. Geology 49, https://doi.org/10.1130/G48795.1 (2021).

8. Wu, Y. et al. Six-fold increase of atmospheric $p \mathrm{CO}_{2}$ during the Permian-Triassic mass extinction. Nat. Commun. 12, 2137 (2021).

9. Burgess, S. D., Muirhead, J. D. \& Bowring, S. A. Initial pulse of Siberian Traps sills as the trigger of the end-Permian mass extinction. Nat. Commun. 8, 164 (2017).

10. Mays, C. et al. Refined Permian-Triassic floristic timeline reveals early collapse and delayed recovery of south polar terrestrial ecosystems. GSA Bull. 132, 1489-1513 (2020).

11. Chu, D. et al. Ecological disturbance in tropical peatlands prior to marine Permian-Triassic mass extinction. Geology 48, 288-292 (2020).

12. Retallack, G. J., Veevers, J. J. \& Morante, R. Global coal gap between Permian-Triassic extinction and Middle Triassic recovery of peat-forming plants. GSA Bull. 108, 195-207 (1996).

13. Fielding, C. R. et al. Age and pattern of the southern high-latitude continental end-Permian extinction constrained by multiproxy analysis. Nat. Commun. 10, 385 (2019).

14. Fielding, C. R. et al. Sedimentology of the continental end-Permian extinction event in the Sydney Basin, eastern Australia. Sedimentology 68, 30-62 (2021).

15. Metcalfe, I., Crowley, J. L., Nicoll, R. S. \& Schmitz, M. High-precision U-Pb CA-TIMS calibration of Middle Permian to Lower Triassic sequences, mass extinction and extreme climate-change in eastern Australian Gondwana. Gondwana Res. 28, 61-81 (2015).

16. Vajda, V. et al. End-Permian (252 Mya) deforestation, wildfires and flooding -an ancient biotic crisis with lessons for the present. Earth Planet. Sci. Lett. 529, 115875 (2020).

17. McLoughlin, S. et al. Dwelling in the dead zone-vertebrate burrows immediately succeeding the end-Permian extinction event in Australia. Palaios 35, 342-357 (2020).

18. Lamb, A. L., Wilson, G. P. \& Leng, M. J. A review of coastal palaeoclimate and relative sea-level reconstructions using $\delta^{13} \mathrm{C}$ and $\mathrm{C} / \mathrm{N}$ ratios in organic material. Earth-Sci. Rev. 75, 29-57 (2006).

19. Mays, C., Vajda, V. \& McLoughlin, S. Permian-Triassic non-marine algae of Gondwana-distributions, natural affinities and ecological implications. Earth-Sci. Rev. 212, 103382 (2021).

20. McLoughlin, S. et al. Age and paleoenvironmental significance of the Frazer Beach Member-a new lithostratigraphic unit overlying the end-Permian extinction horizon in the Sydney Basin, Australia. Front. Earth Sci. 8, 600976 (2021).
21. Huber, J. K. A postglacial pollen and nonsiliceous algae record from Gegoka Lake, Lake County, Minnesota. J. Paleolimnol. 16, 23-35 (1996).

22. Woodward, C. A. \& Shulmeister, J. A Holocene record of human induced and natural environmental change from Lake Forsyth (Te Wairewa), New Zealand. J. Paleolimnol. 34, 481-501 (2005).

23. Pacton, M., Gorin, G. \& Fiet, N. Occurrence of photosynthetic microbial mats in a Lower Cretaceous black shale (central Italy): a shallow-water deposit. Facies 55, 401-419 (2009).

24. Pacton, M., Gorin, G. E. \& Vasconcelos, C. Amorphous organic matterExperimental data on formation and the role of microbes. Rev. Palaeobot. Palynol. 166, 253-267 (2011).

25. Tyson, R. V. Sedimentary Organic Matter: Organic Facies and Palynofacies (Chapman \& Hall, 1995).

26. Retallack, G. J. Earliest Triassic claystone breccias and soil-erosion crisis. J. Sediment. Res. 75, 679-695 (2005).

27. Augland, L. E. et al. The main pulse of the Siberian Traps expanded in size and composition. Sci. Rep. 9, 18723 (2019).

28. Retallack, G. J. Post-apocalyptic greenhouse paleoclimate revealed by earliest Triassic paleosols in the Sydney Basin. Aust. GSA Bull. 111, 52-70 (1999).

29. Woodward, C., Shulmeister, J., Larsen, J., Jacobsen, G. E. \& Zawadzki, A. The hydrological legacy of deforestation on global wetlands. Science 346, 844-847 (2014).

30. Stevenson, R. J. \& Smol, J. P. In Freshwater Algae of North America: Ecology and Classification (eds Wehr, J. D., Sheath, R. G. \& Kociolek, P.) Ch. 21, 921-962 (Academic Press, 2015).

31. Lindström, S., Bjerager, M., Alsen, P., Sanei, H. \& Bojesen-Koefoed, J. The Smithian-Spathian boundary in North Greenland: implications for extreme global climate changes. Geol. Mag. 157, 1547-1567 (2020).

32. de Leeuw, J. W., Versteegh, G. J. M. \& van Bergen, P. F. in Plants and Climate Change, Plant Ecology (eds Rozema, J., Aerts, R. \& Cornelissen, H.) Vol. 182, 209-233 (Springer, 2006).

33. Baudelet, P.-H., Ricochon, G., Linder, M. \& Muniglia, L. A new insight into cell walls of Chlorophyta. Algal Res 25, 333-371 (2017).

34. Graham, L. E. \& Gray, J. In Plants Invade the Land: Evolutionary and Environmental Perspectives (eds Gensel, P. G. \& Edwards, D.) 140-158 (Columbia University Press, 2001).

35. Demura, M., Ioki, M., Kawachi, M., Nakajima, N. \& Watanabe, M. M. Desiccation tolerance of Botryococcus braunii (Trebouxiophyceae, Chlorophyta) and extreme temperature tolerance of dehydrated cells. J. Appl. Phycol. 26, 49-53 (2014).

36. Del Cortona, A. et al. Neoproterozoic origin and multiple transitions to macroscopic growth in green seaweeds. PNAS 117, 2551-2559 (2020).

37. Wheeler, A., Van de Wetering, N., Esterle, J. S. \& Götz, A. E. Palaeoenvironmental changes recorded in the palynology and palynofacies of a Late Permian Marker Mudstone (Galilee Basin, Australia). Palaeoworld 29, 439-452 (2020).

38. Reynolds, C. S., Huszar, V., Kruk, C., Naselli-Flores, L. \& Melo, S. Towards a functional classification of the freshwater phytoplankton. J. Plankton Res. 24, 417-428 (2002).

39. Low-Décarie, E., Fussmann, G. F. \& Bell, G. The effect of elevated $\mathrm{CO}_{2}$ on growth and competition in experimental phytoplankton communities. Glob. Change Biol. 17, 2525-2535 (2011).

40. von Alvensleben, N., Magnusson, M. \& Heimann, K. Salinity tolerance of four freshwater microalgal species and the effects of salinity and nutrient limitation on biochemical profiles. J. Appl. Phycol. 28, 861-876 (2016).

41. Chu, D. et al. Microbial mats in the terrestrial Lower Triassic of North China and implications for the Permian-Triassic mass extinction. Palaeogeog. Palaeoclimatol. Palaeoecol. 474, 214-231 (2017).

42. Guo, W. et al. Secular variations of ichnofossils from the terrestrial Late Permian-Middle Triassic succession at the Shichuanhe section in Shaanxi Province, North China. Glob. Planet. Change 181, 102978 (2019).

43. Lee, J. Y. et al. Future global climate: Scenario-based projections and nearterm information. In Climate Change 2021: The Physical Science Basis. Contribution of Working Group I to the Sixth Assessment Report of the Intergovernmental Panel on Climate Change (eds Masson-Delmotte, V., et al.) 195 pp. (Cambridge University Press, 2021).

44. de Jersey, N. J. Palynology of the Permian-Triassic transition in the western Bowen Basin. Geol. Surv. Qld. Publ. 374, 1-39 (1979).

45. Lindström, S. \& McLoughlin, S. Synchronous palynofloristic extinction and recovery after the end-Permian event in the Prince Charles Mountains, Antarctica: Implications for palynofloristic turnover across Gondwana. Rev. Palaeobot. Palynol. 145, 89-122 (2007).

46. Grebe, H. Permian plant microfossils from the Newcastle Coal Measures/ Narrabeen Group Boundary, Lake Munmorah, New South Wales. Rec. Geol. Surv. NSW 12, 125-136 (1970).

47. Mishra, S. et al. A new acritarch spike of Leiosphaeridia dessicata comb. nov. emend. from the Upper Permian and Lower Triassic sequence of India 
(Pranhita-Godavari Basin): its origin and palaeoecological significance. Palaeogeog. Palaeoclimatol. Palaeoecol. 567, 110274 (2021).

48. Grice, K. et al. Photic zone euxinia during the Permian-Triassic superanoxic event. Science 307, 706-709 (2005)

49. Kershaw, S. et al. Microbialites and global environmental change across the Permian-Triassic boundary: a synthesis. Geobiology 10, 25-47 (2012).

50. Schneebeli-Hermann, E. et al. Palynofacies analysis of the Permian-Triassic transition in the Amb section (Salt Range, Pakistan): implications for the anoxia on the South Tethyan Margin. J. Asian Earth Sci. 60, 225-234 (2012).

51. van Soelen, E. E. \& Kürschner, W. M. Late Permian to Early Triassic changes in acritarch assemblages and morphology in the Boreal Arctic: new data from the Finnmark Platform. Palaeogeog. Palaeoclimatol. Palaeoecol. 505, 120-127 (2018).

52. Spina, A., Cirilli, S., Utting, J. \& Jansonius, J. Palynology of the Permian and Triassic of the Tesero and Bulla sections (Western Dolomites, Italy) and consideration about the enigmatic species Reduviasporonites chalastus. Rev. Palaeobot. Palynol. 218, 3-14 (2015).

53. Thomas, B. M. et al. Unique marine Permian-Triassic boundary section from Western Australia. Aust. J. Earth Sci. 51, 423-430 (2004).

54. Schneebeli-Hermann, E. \& Bucher, H. Palynostratigraphy at the PermianTriassic boundary of the Amb section, Salt Range, Pakistan. Palynology 39, 1-18 (2015).

55. Lei, Y. et al. Phytoplankton (acritarch) community changes during the Permian-Triassic transition in South China. Palaeogeog. Palaeoclimatol. Palaeoecol. 519, 84-94 (2019).

56. Algeo, T. J. et al. Plankton and productivity during the Permian-Triassic boundary crisis: An analysis of organic carbon fluxes. Glob. Planet. Change 105, 52-67 (2013).

57. van Soelen, E. E., Twitchett, R. J. \& Kürschner, W. M. Salinity changes and anoxia resulting from enhanced run-off during the late Permian global warming and mass extinction event. Climate 14, 441-453 (2018).

58. Kaiho, K. et al. Effects of soil erosion and anoxic-euxinic ocean in the Permian-Triassic marine crisis. Heliyon 2, e00137 (2016).

59. Bond, D. P. G. \& Grasby, S. E. On the causes of mass extinctions. Palaeogeog. Palaeoclimatol. Palaeoecol. 478, 3-29 (2017).

60. Lindström, S., Erlström, M., Piasecki, S., Nielsen, L. H. \& Mathiesen, A. Palynology and terrestrial ecosystem change of the Middle Triassic to lowermost Jurassic succession of the eastern Danish Basin. Rev. Palaeobot. Palynol. 244, 65-95 (2017)

61. Garel, S. et al. Paleohydrological and paleoenvironmental changes recorded in terrestrial sediments of the Paleocene-Eocene boundary (Normandy, France). Palaeogeog. Palaeoclimatol. Palaeoecol. 376, 184-199 (2013).

62. van de Schootbrugge, B. \& Gollner, S. In Ecosystem Paleobiology and Geobiology, The Paleontological Society Papers (eds Bush, A. M., Pruss, S. B. \& Payne, J. L.) 19, 87-114 (The Paleontological Society, 2013).

63. Mata, S. A. \& Bottjer, D. J. Microbes and mass extinctions: paleoenvironmental distribution of microbialites during times of biotic crisis. Geobiology 10, 3-24 (2012).

64. Peterffy, O., Calner, M. \& Vajda, V. Early Jurassic microbial mats-a potential response to reduced biotic activity in the aftermath of the endTriassic mass extinction event. Palaeogeog. Palaeoclimatol. Palaeoecol. 464, 76-85 (2016).

65. Schoene, B. et al. U-Pb constraints on pulsed eruption of the Deccan Traps across the end-Cretaceous mass extinction. Science 3636, 862-866 (2019).

66. Hull, P. M. et al. On impact and volcanism across the Cretaceous-Paleogene boundary. Science 367, 266-272 (2020).

67. Vajda, V., Ocampo, A., Ferrow, E. \& Bender Koch, C. Nano particles as the primary cause for long-term sunlight suppression at high southern latitudes following the Chicxulub impact-evidence from ejecta deposits in Belize and Mexico. Gondwana Res. 27, 1079-1088 (2015).

68. Sepúlveda, J., Wendler, J. E., Summons, R. E. \& Hinrichs, K.-U. Rapid resurgence of marine productivity after the Cretaceous-Paleogene mass extinction. Science 326, 129-132 (2009).

69. Bralower, T. J. et al. Origin of a global carbonate layer deposited in the aftermath of the Cretaceous-Paleogene boundary impact. Earth Planet. Sci. Lett. 548, 116476 (2020).

70. Schaefer, B. et al. Microbial life in the nascent Chicxulub crater. Geology 48, 328-332 (2020).

71. Milligan, J. N., Royer, D. L., Franks, P. J., Upchurch, G. R. \& McKee, M. L. No evidence for a large atmospheric $\mathrm{CO}_{2}$ spike across the Cretaceous-Paleogene boundary. Geophys. Res. Lett. 46, 3462-3472 (2019).

72. Strother, P. K. \& Wellman, C. H. The Nonesuch Formation Lagerstätte: a rare window into freshwater life one billion years ago. J. Geol. Soc. 178, jgs2020-jgs2133 (2021)

73. Sepkoski, J. J., Bambach, R. K. \& Droser, M. L. In Cycles and Events in Stratigraphy (eds Einsele, G., Ricken, W. \& Seilacher, A.) 298-312 (SpringerVerlag, 1991).
74. Tyson, R. V. Calibration of hydrogen indices with microscopy: a review, reanalysis and new results using the fluorescence scale. Org. Geochem. 37, $45-63$ (2006)

75. Benninghoff, W. S. Calculation of pollen and spore density in sediments by addition of exotic pollen in known quantities. Pollen et. Spores 4, 332-333 (1962).

76. Maher, L. J. Statistics for microfossil concentration measurements employing samples spiked with marker grains. Rev. Palaeobot. Palynol. 32, 153-191 (1981).

77. Simpson, M. G. Plant Systematics (Academic Press, 2019).

78. Evitt, W. R. A discussion and proposals concerning fossil dinoflagellates, hystrichospheres, and acritarchs, II. PNAS 49, 298-302 (1963).

79. Rampino, M. R. \& Eshet, Y. The fungal and acritarch events as time markers for the latest Permian mass extinction: an update. Geosci. Front. 9, 147-154 (2018).

80. Combaz, A. Les palynofaciès. Rev. Micropaléontol. 7, 205-218 (1964).

81. Hammer, Ø., Harper, D. A. T. \& Ryan, P. D. PAST: paleontological statistics software package for education and data analysis. Palaeontol. Electron. 4, 4 (2001).

82. Wei, W. \& Algeo, T. J. Elemental proxies for paleosalinity analysis of ancient shales and mudrocks. Geochim. Cosmochim. Acta 287, 341-366 (2020).

83. Rowe, H., Hughes, N. \& Robinson, K. The quantification and application of handheld energy-dispersive $\mathrm{x}$-ray fluorescence (ED-XRF) in mudrock chemostratigraphy and geochemistry. Chem. Geol. 324-325, 122-131 (2012).

84. Blakey, R. C. Global paleogeography and tectonics in deep time. https:// deeptimemaps.com/global-series-details/. Accessed 16 June 2020 (2016).

85. Zhuravlev, A. Y. \& Wood, R. A. Anoxia as the cause of the mid-Early Cambrian (Botomian) extinction event. Geology 24, 311-314 (1996).

86. Zhang, W., Shi, X., Jiang, G., Tang, D. \& Wang, X. Mass-occurrence of oncoids at the Cambrian Series 2-Series 3 transition: Implications for microbial resurgence following an Early Cambrian extinction. Gondwana Res. 28, 432-450 (2015).

87. Vecoli, M. Fossil microphytoplankton dynamics across the Ordovician-Silurian boundary. Rev. Palaeobot. Palynol. 148, 91-107 (2008).

88. Xie, S. et al. Contrasting microbial community changes during mass extinctions at the Middle/Late Permian and Permian/Triassic boundaries. Earth Planet. Sci. Lett. 460, 180-191 (2017).

89. Eshet, Y., Rampino, M. R. \& Visscher, H. Fungal event and palynological record of ecological crisis and recovery across the Permian-Triassic boundary. Geology 23, 967-970 (1995).

90. Richoz, S. et al. Hydrogen sulphide poisoning of shallow seas following the end-Triassic extinction. Nat. Geosci. 5, 662-667 (2012).

91. Lindström, S. et al. No causal link between terrestrial ecosystem change and methane release during the end-Triassic mass extinction. Geology 40, 531-534 (2012).

92. van de Schootbrugge, B. et al. End-Triassic calcification crisis and blooms of organic-walled "disaster species". Palaeogeog. Palaeoclimatol. Palaeoecol. 244, 126-141 (2007).

93. Slater, S. M., Twitchett, R. J., Danise, S. \& Vajda, V. Substantial vegetation response to Early Jurassic global warming with impacts on oceanic anoxia. Nat. Geosci. 12, 462-467 (2019).

94. Polgári, M. et al. Mineral and chemostratigraphy of a Toarcian black shale hosting Mn-carbonate microbialites (Úrkút, Hungary). Palaeogeog. Palaeoclimatol. Palaeoecol. 459, 99-120 (2016).

95. $\mathrm{Xu}, \mathrm{W}$. et al. Carbon sequestration in an expanded lake system during the Toarcian oceanic anoxic event. Nat. Geosci. 10, 129-134 (2017).

96. Kashiyama, Y. et al. Diazotrophic cyanobacteria as the major photoautotrophs during mid-Cretaceous oceanic anoxic events: nitrogen and carbon isotopic evidence from sedimentary porphyrin. Org. Geochem. 39, 532-549 (2008).

97. Jarvis, I. et al. Microfossil assemblages and the Cenomanian-Turonian (late Cretaceous) oceanic anoxic event. Cretac. Res 9, 3-103 (1988).

98. Layeb, M., Ben Fadhel, M., Layeb-Tounsi, Y. \& Ben Youssef, M. First microbialites associated to organic-rich facies of the Oceanic Anoxic Event 2 (Northern Tunisia, Cenomanian-Turonian transition). Arab. J. Geosci. 7, 3349-3363 (2014).

99. Pearce, M. A., Jarvis, I. \& Tocher, B. A. The Cenomanian-Turonian boundary event, OAE2 and palaeoenvironmental change in epicontinental seas: new insights from the dinocyst and geochemical records. Palaeogeog. Palaeoclimatol. Palaeoecol. 280, 207-234 (2009).

100. Kuypers, M. M. M., Pancost, R. D., Nijenhuis, I. A. \& Sinninghe Damsté, J. S Enhanced productivity led to increased organic carbon burial in the euxinic North Atlantic basin during the late Cenomanian oceanic anoxic event. Paleoceanography 17, 1051 (2002).

101. Dodsworth, P., Eldrett, J. S. \& Hart, M. B. Cretaceous Oceanic Anoxic Event 2 in eastern England: further palynological and geochemical data from Melton Ross. figshare https://doi.org/10.6084/m9.figshare.c.4987205.v3 (2020). 
102. Schwab, K. W., Bayliss, G. S., Smith, M. A. \& Yoder, N. B. Mushroom and broccoli-head shaped algal fragments from the Eagle Ford Shale of south Texas and Coahuila, Mexico. Search and Discovery 70134 (2013).

103. Lyson, T. R. et al. Exceptional continental record of biotic recovery after the Cretaceous-Paleogene mass extinction. Science 366, 977-983 (2019).

104. Scasso, R. A. et al. A high-resolution record of environmental changes from a Cretaceous-Paleogene section of Seymour Island. Antarctica. Palaeogeog. Palaeoclimatol. Palaeoecol. 555, 109844 (2020).

105. Sosa-Montes de Oca, C. et al. Minor changes in biomarker assemblages in the aftermath of the Cretaceous-Paleogene mass extinction event at the Agost distal section (Spain). Palaeogeog. Palaeoclimatol. Palaeoecol. 569, 110310 (2021).

106. Sluijs, A. et al. Environmental precursors to rapid light carbon injection at the Palaeocene/Eocene boundary. Nature 450, 1218-1222 (2007).

107. Junium, C. K., Dickson, A. J. \& Uveges, B. T. Perturbation to the nitrogen cycle during rapid Early Eocene global warming. Nat. Commun. 9, 3186 (2018).

108. Pagani, M. et al. Arctic hydrology during global warming at the Palaeocene/ Eocene thermal maximum. Nature 442, 671-675 (2006).

109. Kender, S. et al. Marine and terrestrial environmental changes in NW Europe preceding carbon release at the Paleocene-Eocene transition. Earth Planet. Sci. Lett. 353-354, 108-120 (2012).

110. Huisman, J. et al. Cyanobacterial blooms. Nat. Rev. Microbiol. 16, 471-483 (2018).

111. Paerl, H. W., Hall, N. S. \& Calandrino, E. S. Controlling harmful cyanobacterial blooms in a world experiencing anthropogenic and climaticinduced change. Sci. Tot. Environ. 409, 1739-1745 (2011).

\section{Acknowledgements}

Bob Nicoll, Jim Crowley, and Malcolm Bocking for advice on radiogenic isotope age controls and stratigraphic relationships of Sydney Basin units. Cornelia \& Arne Winguth for advice on Early Triassic climates. Jane Sibbons and Robert Hill at the University of Adelaide for assistance with fluorescence microscopy. This research was funded by the Swedish Research Council (grants 2015-04264, 2018-04527, 2019-04061, 2019-04524) and the National Science Foundation (grant EAR-1636625).

\section{Author contributions}

C.M.: Conceptualization, data curation, palynological and palaeoenvironmental analysis, and writing the original draft. V.V.: Funding acquisition, conceptualization, data cura- tion, palynological analysis, writing, and editing. S.M.: Funding acquisition, conceptualization, data curation, macrofloral analysis, writing, and editing. T.F.: Funding acquisition, data curation, geochemical analysis, writing, and editing. C.F.: Funding acquisition, data curation, sedimentological analysis, writing, and editing. S.S.: Comparative mass extinction dynamics and algal ecology, writing, and editing.

\section{Competing interests}

The authors declare no competing interests.

\section{Additional information}

Supplementary information The online version contains supplementary material available at https://doi.org/10.1038/s41467-021-25711-3.

Correspondence and requests for materials should be addressed to Chris Mays or Vivi Vajda.

Peer review information Nature Communications thanks Cindy Looy, Daniel Peyrot and Simonetta Cirilli for their contribution to the peer review of this work. Peer reviewer reports are available.

Reprints and permission information is available at http://www.nature.com/reprints

Publisher's note Springer Nature remains neutral with regard to jurisdictional claims in published maps and institutional affiliations.

\section{(c) (i)}

Open Access This article is licensed under a Creative Commons Attribution 4.0 International License, which permits use, sharing, adaptation, distribution and reproduction in any medium or format, as long as you give appropriate credit to the original author(s) and the source, provide a link to the Creative Commons license, and indicate if changes were made. The images or other third party material in this article are included in the article's Creative Commons license, unless indicated otherwise in a credit line to the material. If material is not included in the article's Creative Commons license and your intended use is not permitted by statutory regulation or exceeds the permitted use, you will need to obtain permission directly from the copyright holder. To view a copy of this license, visit http://creativecommons.org/ licenses/by/4.0/

(C) The Author(s) 2021 